Financial Markets, Institutions and Risks, Volume 3, Issue 2, 2019

ISSN (online) - 2521-1242 ISSN (print) - 2521-1250

\title{
Industrial Policy and Industrial Sector Productivity in Nigeria
}

\author{
http://doi.org/10.21272/fmir.3(2).44-51.2019
}

Akinwale1, S.O.

$\mathrm{PhD}$, Department of Banking and Finance, Adekunle Ajasin University Akungba-Akoko, Ondo State, Nigeria

\section{Adekunle, E. Oludayo1}

Department of Banking and Finance, Adekunle Ajasin University Akungba-Akoko, Ondo State, Nigeria

\begin{abstract}
Industrial sector serves as an effective tool of promoting growth and development. However, in the recent years, Nigerian industrial sector has significantly been underperforming which prompted the need to investigate the effect of industrial policy on industrial sector productivity. The study adopted secondary data from Central Bank of Nigerian Statistical Bulletin which covered the period of 1986 to 2017 and analyzed using Augmented Dickey Fuller Unit Root Test, Johansen Co-integration and Error Correction Model. The result of the unit root test revealed that industrial output, trade openness, exchange rate, credit to private sector and government capital spending were stationary first difference while the Johansen Co-integration test indicated that there is long run relationship among the varaibles. The result of the error correction model showed that trade openness produced insignificant and negative effect on industrial output. Also, the result showed that exchange rate had statistically insignificant and positive effect on industrial output. Furthermore, government capital spending exerted positive and significant effect on industrial output and finally, credit to private sector is statistically significant in predicting the value of industrial output in Nigeria. The result of the granger causality test revealed trade openness and government capital expenditure did not granger caused industrial output while exchange rate and credit to private sector granger caused industrial output. Thus, the study concluded that industrial policy has been partly effective in influencing industrial sector productivity in Nigeria. In light of this government should formulate and implement policies that will advance trade and economic integration between the country and international countries in order to enable industrial sector enjoy the opportunities of foreign cooperation.
\end{abstract}

Keywords: Government Capital Spending, Exchange Rate, Industrial Output, Industrial Policy and Trade Openness.

JEL Classification: L 51, L52, H54, H8.

(C) The Authors, 2019. This article is published with open access at Sumy State University.

Cite as: Akinwale, S.O., Oludayol Ad., E. (2019). Industrial Policy and Industrial Sector Productivity in Nigeria. Financial Markets, Institutions and Risks, 3(2), 44-51. http://doi.org/10.21272/fmir.3(2).44-51.2019.

\section{Introduction}

In an attempt to facilitate industrialization in the country, over the years, different industrial policies/industrialization strategies as well as policy reform measures have been formulated and implemented. Since 1960, major African continent perceived industrialization as a tool of promoting self-reliance and reducing over dependency on developed economies (Isiksa \& Chimezie, 2016).

The industrial sector of an economy plays a significant role in the development of a nation. It represents group of firms that involves in the transformation of factors of productions to finished goods and services. The industrial sector serves an instrument of sustainable growth and development by increasing productive capacity, enhancing revenue, creating employment opportunities, ensuring effective income distribution, poverty reduction, contribution to export and gross domestic product (Okoye, Nwakoby \& Okories, 2016). Industrial policy involves government intervention in embarking on powerful reforms that will assist widening sectoral base of the economy (Aza \& Dodo, 2014). It is a potent instrument for resuscitating and enhancing industrial sector performance in stimulating rapid economic growth and development through effectiveness and efficiency in the utilization of the resources capacity of the economy (Felix \& Emmanuel, 2015).

Nigerian economy has been anchored upon industrial led economy before independence based on the fact that well industrialized nation has the capacity of promoting growth and development. As result of this, since 
independence government has adopted numerous strategies and industrial reforms in order to enhance the growth and development of the industrial sector (Okoye, et al., 2016). Some of these strategies include Import Substitution Strategy, Export Promotion Strategy and Local resource-based Strategy, Nigerian indigenization policy, trade and financial liberalization and Structural Adjustment Programmes (SAP) among others (Ekpo, 2014). These policies and other reforms were aimed at opening the Nigerian economy to the rest of the world, enhance industrial production capacity and positioned the industrial sector as driver of growth and long-term development.

However, in spite of policy the frameworks and reforms formulated, there are still growing concern on the industrial sector's contribution to the nation's gross domestic product. The production of industrial sector increased from N6,157.84 billion in 2006 to N6,800.15 billion and N 8,072.50 billion in 2007 and 2008 respectively (CBN, 2017). However, industrial sector output fell to N7,513.88 billion in 2009 and rose to N12,033.20 billion and N15,626.42 billion in 2010 and 2011 respectively. Furthermore, the productivity of the industrial sector continues to grow through 2012, 2013 and 2014 with value of N16,975.34 billion, N17,614.29 billion and N18,402.19 billion respectively. However, the sector recorded a decreased to N15,073.78 billion and N14,372.78 billion in both 2015 and 2016 respectively before rising N20,526.46 billion in 2017 (CBN, 2017).

From the above statistics, it was revealed that the industrial sector has witnessed significant growth in terms of productivity. However, in terms of the sector's contribution to gross domestic product, the trends have been very poor as revealed by Central Bank of Nigeria Statistical Bulletin with a value of $20.6 \%$ and $20.2 \%$ in 2007 and 2008 respectively which later fell again to $16.9 \%$ in 2009 (CBN, 2017). However, the sector's contribution to gross domestic product rose to $22 \%$ and $24 \%$ in 2010 and 2011 respectively before falling to $23.7 \%, 21.9 \%, 20.6 \%, 16.0 \%$ and $14.20 \%$ in $2012,2013,2014,2015$ and 2016 respectively and later rose to $18 \%$ in 2017 (CBN, 2017).

Recently, the Nigerian economy is faced with the challenges of high poverty rate, high unemployment rate, over dependency on crude oil at the expense of agricultural sector and manufacturing sector, over reliance on import goods and services and balance of trade deficit. These challenges questioned the effectiveness of government policy in the economy. Thus, this study examined the effect of industrial policy on industrial sector performance in Nigeria. The rest of the paper was structured into literature review, methodology, presentation of results and interpretation and finally conclusion and recommendations.

\section{Literature Review}

The industrial sector comprises of different sector of the economy which involves manufacturing sector, agricultural sector, mining sector, oil and gas, banking sector and services among others. Industrial policy is a set of porgramme initiated by the government aimed at fast tracking the development of a particular sector (Aza \& Dodo, 2014).

The industrial sector is one of the major sectors in the economy because of the role it plays in development and growth process of a nation. The sector has the capacity to lead the economy in terms of employment creation, foreign earnings, export promotion and growth enhancement (Onakoya et al., 2012). Industrial policy serves as potent tool for enhancing the productivity and performance of industrial sector through increase efficiency and effectiveness of the sector. According to Chang (2003), industrial policy through governmental actions supports the production and technological capacity of industries in economy. Duru (2012) opined that effective industrial policy focused on expansionary fiscal and monetary policy which serve as incentives for investment, investment in public infrastructures by government, massive investment in research and development by giving invectives to industrial sector and policies to support the activities of small and medium enterprises

Udegbunam (2002) studied the effect of trade openness on industrial output growth in Nigeria using data for the period 1970-1997 which were analyzed using ordinary least square and it was revealed that trade openness is a major determinant of industrial output growth in Nigeria. Also, Bakare and Fawehinmi (2011) investigated the impact of trade openness on industrial output. The multiple regression found that public domestic investment, savings rate, capacity utilization and infrastructure had negative impact on industrial output performance in Nigeria. Onakoya, Fasanya and Babalola (2012) examined the impact of trade openness on manufacturing sector performance in the Nigerian economy, using a time series data from 1975 to 2010. The effects of stochastic shocks of each of the endogenous variables are explored using Error Correction Model (ECM). 
Financial Markets, Institutions and Risks, Volume 3, Issue 2, 2019

ISSN (online) - 2521-1242 ISSN (print) - 2521-1250

The analysis showed that trade openness is positively related to the performance of the manufacturing sector while exchange rate, inflation rate has a negative impact on the sector performance. The error correction coefficient also indicated rate of adjustment for disequilibrium of the variables shows that growth in the manufacturing sector adjust slowly in the economy.

Afaha and Njogo (2012) investigated the impact of trade openness on the Nigerian economy using data over the period 1970-2010 by employing the technique of the ordinary least squares (OLS), it was found that there was positive and significant relationship between trade openness and growth. In his study, Tawose (2012) examined the effect of public expenditure on industrial sector productivity in Nigeria. Ordinary least square multiple regression was adopted to carry out analysis on the relationship that exist between public expenditure and industrial sector productivity. The regression resulted showed that both government expenditure on administration and government expenditure on economic services had negative relationships with industrial productivity.

Umoru and Eborieme (2013) investigated the relation between trade liberalization and industrial growth in Nigeria by employing co-integration and error correction estimation approaches were utilized. A unique cointegral relation between industrial production and the explanatory variables in the study was found and the empirical findings revealed that there is a positive and significant correlation between trade liberalization and industrial growth in Nigeria. Okoye, Nwakoby and Okorie, (2016) studied the extent to which economic deregulation policy influence the performance of the real sector in Nigeria using vector error correction model and it was found that exchange rate and trade openness exerted significant positive impact on industrial output in Nigeria. Isiksa and Chmizie (2016) explored the relationship between GDP, agriculture (AR), industry (ID) and services sector (SV) in Nigeria. The Johansen co-integration testing approach demonstrated a significant long-run relationship between these three variables. The results revealed that agriculture, industry and services had significant positive relationship with GDP. The Causality results demonstrated a bidirectional causal relationship between GDP, AR, ID and SV. Adofu and Okwanya (2017) examined the effect of trade openness and total factor productivity on industrial output in Nigeria using VAR. The data used for this analysis covered the period 1981 and 2015. The results showed that trade openness had a positive increasing effect on industrial output in Nigeria while the effect of total factor productivity on industrial output is found to be insignificant.

Maryam and Bassey (2018) evaluated the effect of industrial sector on economic growth in Nigeria. The result of the OLS revealed that industrial output has an effect on economic growth in Nigeria Ugwuanyi and Nkem (2017) carried out a study to analyze the relationship between industrialization drivers and Nigeria economic growth from 1980 to 2014 using time series data. The methodology employed was Unit Root Test, Co-integration Test, Error Correction model and Granger Causality Test in determining the objectives of the research. Findings revealed that Foreign Direct Investment (FDI), Financial System Development which is proxy with Aggregate Bank Lending (ABL) and Exchange Rate (EXR) significantly stimulate the Nigeria economy while Trade Openness negatively influences economic growth in the long run.

From the review of past literature, studies have focused mainly on the relationship between reforms and manufacturing sector (Onakoya et al., 2012; Nyor \& Chinge, 2014; Felix \& Emmanuel, 2015; Adofu \& Okwanya, 2017). Also, Isiksa and Chmizie (2016); Ugwuanyi and Nkem (2017); Maryam and Bassey (2018) investigated the effect of industrialization on economic growth. However, study has not been conducted on the effect of industrial policy on productivity of industrial sector in Nigeria. Also, the direction of relationships between industrial policy and productivity has not yet been established. Furthermore, previous studies ignored government capital spending and credit to private sector in their analysis as the determinants of industrial sector productivity. Thus, in line with the above gap this study assessed the relationship between industrial policy and industrial sector productivity in Nigeria.

\section{Methods}

This paper focused the effect of industrial policy on industrial sector productivity in Nigeria. The study adopts quantitative method to assess the relationship between trade openness, exchange rate, government capital spending, credit to private sector and industrial output in Nigeria based on ex post facto research design. Data for the study were obtained from Central Bank of Nigerian Statistical Bulletin (2017) from 1986 to 2017. The study adapted the empirical model of Okoye et al., (2016) which is given as:

$\mathrm{INO}=f(\mathrm{TOP}, \mathrm{EXR}, \mathrm{GCE}, \mathrm{CPS})$

The equation for the above model is given as: 
$\mathrm{INO}_{\mathrm{t}}=\lambda_{0}+\lambda_{1} \mathrm{TOP}_{\mathrm{t}}+\lambda_{2} \mathrm{EXR}_{\mathrm{t}}+\lambda_{3} \mathrm{GCE}_{\mathrm{t}}+\lambda_{3} \mathrm{CPS}_{\mathrm{t}}+\mathrm{e}_{\mathrm{t}}$

Where: INO = Industrial Output, TOP $=$ Trade Openness which is measured as the sum of total export and import divided by gross domestic product. EXR $=$ Exchange Rate, $\mathrm{GCS}=$ Government Capital Spending and CPS $=$ Credit to Private Sector

$\lambda_{0}=$ Constant,$\lambda_{1}-\lambda_{4}=$ Coefficient of the parameters, $\mathrm{e}=$ Error Term.

\section{Method of Data Analysis}

This study employed Augmented Dickey-Fuller (ADF), Johansen Co-integration Test and Error Correction Model to examine the effect of industrial policy on industrial productivity in Nigeria. The stationary of the variables was conducted using Augmented Dickey Fuller test.

Following the unit root test, the study proceeded to co-integration testing to determine whether there is long run relationship among the variables. For this purpose, the study used Johannes co-integration test. Based on the discovery of long run relationship among the varaibles, Error Correction Model was adopted in order to establish the short run relationship among the variables. The economic parameters employed in the study include T-statistic, Adjusted R-Squared and F-statistics which are used to establish the level of significance between the independent variables proxy as Trade Openness, Exchange Rate, Government Capital Spending, Credit to Private Sector and Industrial Output.

Finally, the study employed Pairwise Granger Causality for the purpose of establishing the direction of causality between Exchange Rate, Trade Openness and Industrial Policy and the dependent variables namely Trade Openness, Exchange Rate, Government Capital Spending, Credit to Private Sector and Industrial Output.

\section{Presentation and Interpretation of Results}

In this section, result from the data analysis are presented and analyzed. The section presents result on correlation matrix, ADF unit root, Johansen Co-integration, Error Correction Model and Pairwise Granger Causality Test.

\section{Correlation Matrix}

Appendix 1 revealed that the variables have low correlation values indicating absence of multi-collinearity. The result shows that their trade openness and exchange rate have indirect correlation with industrial productivity while government capital spending and credit to private sector are directly correlated with industrial output.

\section{Summary of Unit Root Test}

The ADF unit root result in Appendix 2 shows that industrial output, trade openness, exchange rate, government capital spending and credit to private sector are have the problem of unit root at level because their test statistics are greater than their respective critical values. However, all the varaibles were integrated at 1(I) which implies that the variables are free from the problem of unit root at first difference.

\section{Co-Integration Test}

The result of the Johansen Co-integration presented in appendix 3 shows that, there is long run relationship among the varaibles leading to the rejection of the null hypothesis that there is no long run relationship between industrial output, trade openness, exchange rate, government capital spending and credit to private sector.

\section{Interpretation of Model Results}

The result of the study is presented in appendix 4. The result of the analysis shows that Error Correction Model has a negative sign of -0.783707 which is significant at $5 \%$ with a probability value of 0.0012 which implies that there is speed of adjustment among the variables. It shows a high speed of adjustment to short-run shocks of about 78 per cent. Hence the short run deviations from equilibrium position were readjusted to maintain balance in the system by the variables in the long-run.

The result shows that trade openness does not simulate industrial output in Nigeria which implies that $1 \%$ increase in trade openness will lead to $12 \%$ fall in industrial output in Nigeria. This finding does not conform 
Financial Markets, Institutions and Risks, Volume 3, Issue 2, 2019

ISSN (online) - 2521-1242 ISSN (print) - 2521-1250

with the result of Edame and Karimo (2014); Adofu and Okwanya (2017) that there is positive relationship between trade openness and industrial output in Nigeria.

The result shows that exchange rate enhances industrial output with a coefficient of 0.122038 indicating that $1 \%$ increase in exchange rate will lead to 0.122038 rise in industrial output. This result is supported by the findings of Okoye et al., (2016) which established positive relationship between exchange rate and industrial output.

Similarly, government capital spending promotes industrial output such that as government capital spending increase by $1 \%$ thereby leading to $11 \%$ increase in industrial output. Finally, credit to private sector negatively influenced industrial output meaning that $1 \%$ increase in credit to private sector will result in $47 \%$ fall in industrial output in Nigeria. However, the findings are not in line with the findings of Okoye et al., (2016) which revealed positive relationship between credit to private sector and industrial output in Nigeria.

\section{Diagnostics Test}

Appendix 5 shows the result of the reliability test for the study. The table shows that regression residual is normally distributed with a probability value of 0.35256 which is greater than the acceptance region of 0.05 . Also, the serial correlation test revealed that their regression is not serially correlated with a p-value of 0.1096 . Finally, the regression estimate has no problem of Heteroskedasticity has indicated by the Breusch-PaganGodfrey test with a p-value of 0.2142 which is insignificant at $5 \%$.

\section{Stability Test}

The result of the Cusum stability test is presented in figure 1 . The result reveals that the Cusum stability line is within the acceptance region of 5\% significance level thereby leading to the conclusion that the regression model is stable.

\section{Granger Causality Test}

Appendix 6 the result shows that there is independent relationship between trade openness and industrial output which implies that trade openness does not granger cause industrial output in Nigeria. Furthermore, bidirectional relationship was found between exchange rate and industrial output with causality running between the macroeconomic variables indicating that exchange rate granger causes industrial output in Nigeria. However, independent relationship was established between government capital spending and industrial output which implies that government capital spending does not granger cause industrial output in Nigeria. Finally, bidirectional relationship was found between credit to private sector and industrial output with causality running between the macroeconomic variables indicating that credit to private sector cause industrial output in Nigeria.

\section{Conclusion and Recommendations}

The industrial sector is of great significance in the economy given the role it plays in employment creation, foreign earnings generation and contribution to gross domestic product. In order to enhance the efficiency and competiveness of industrial sector, the government over the years has formulated diverse policies among which trade policies plays leading role. Thus, this study investigated the effect of industrial policy on industrial productivity in Nigeria.

The study found that trade openness and exchange rate had insignificant effect on industrial output while government capital spending and credit to private sector exerted significant effect on industrial output with credit to private sector being negative. Thus, the study concluded that industrial policy had ineffective impact on industrial sector productivity in Nigeria. It was thus recommended that government should formulate and implement policies that will advance trade and economic integration between the country and international countries in order to enable industrial sector enjoy the opportunities of foreign cooperation. More credit should also be given to the industrial sector my financial institutions and government should ensure that more budget is allocated in the provision of major infrastructural facilities that will support the activities of the industrial sector.

\section{Interpretation of Model Results}


The value of the Adjusted R-squared as indicated in Appendix 4 is given as 0.684764 which is an indication that the regression model is fairly reliable. The implication of this is that, trade openness, exchange rate, government capital spending and credit to private sector explained $68 \%$ changes in industrial output while the remaining $32 \%$ was as a result of other factors not captured in the model.

This study employed F-statistic in order to test the overall significance of the regression result. The F-statistic which gives a value of 4.022727 with a probability of 0.006711 is significant at $5 \%$ implies that industrial policy has significant effect on industrial sector output in Nigeria. It indicates that, trade openness, exchange rate, government capital spending and credit to private sector jointly and significantly influenced industrial output in Nigeria.

\section{References}

1. Adofu, I. \& Okwanya, I (2017). Linkages between trade openness, productivity and industrialization in Nigeria: A co-integration test. Research in World Economy, 8(2), 78-87.

2. Afaha, J.S. \& Njogo, B.O. (2012). Trade openness and its effect on the Nigerian economy, Arabian Journal of Business and Management Review, 2(1), 13-26

3. Aza, N.G. \& Dodo, C.E. (2014). The impacts of industrial policies on the manufacturing sector in Nigeria: An assessment. Research on Humanities and Social Sciences, 4(21), $111-120$.

4. Bakare, A.S. \& Fawehinmi, F.O. (2011). Trade openness and its impact on Nigeria's non- oil industrial sector. Economics and Finance Review, 1(5), 57-65.

5. Central Bank of Nigeria (2017). Central Bank of Nigeria Statistical Bulletin. CBN: Abuja.

6. Chang, H.J. (2003). Kicking away the ladder: infant industry promotion in historical perspective, Oxford University Press, Oxford.

7. Duru, M. (2012). New challenges for industrial policy in Nigeria. Universal Journal of Management and Social Sciences, 2(1), 13-23.

8. Isiksa, A.Z. \& Chimezie, O.J. (2016). Impact of industrialization in Nigeria. European Scientific Journal, 12(10), 328-339.

9. Maryam, A. \& Bassey, E.M. (2018). Evaluation of the Nigerian industrial sector and economic growth in the face of sustainable development goals. International Journal of Advanced Research in Public Policy, Social Development and Enterprise Studies, 3(1), 49 - 59.

10. Okoye, L.A. \& Nwakoboy, E.I.N. \& Okorie, C.U. (2016). Deregulating the Nigerian economy for enhanced real sector growth. Journal of Policy and Development Studies, 10(2), 144 - 158.

11. Onakoya, A.B.O., Fasanya, I.O. \& Babalola, M.T. (2012). Trade openness and manufacturing sector growth: An empirical analysis for Nigeria. Mediterranean Journal of Social Sciences, 3(11), 637-646.

12. Tawose, J. (2012). Effects of public expenditure on industrial sector productivity in Nigeria. Canadian Social Science, 89(1), 204-214.

13. Udegbunam, R.I. (2002). Openness, stock market development and industrial growth in Nigeria, $P a$ kistan Development Review, 41(1), 69-92.

14. Ugwuanyi, C.U., \& Nkem, M.N. (2017). Industrialization drivers and Nigeria economic Growth. International Journal of Science and Research Methodology, 6(4).

15. Umoru, D. \& Eboriem, M. (2013). Trade liberalization and industrial growth in Nigeria. Journal of Poverty, Investment and Development, 1(1), 148-156.

\section{Appendix}

\begin{tabular}{|c|c|c|c|c|c|}
\hline \multicolumn{7}{|c|}{ Table 1. Correlation Matrix } \\
\hline INO & INO & TOP & EXR & GCS & CPS \\
\hline TOP & -0.173375 & 1.0000000 & & & \\
\hline EXR & -0.006858 & 0.104282 & 1.000000 & & \\
\hline GCS & 0.200571 & -0.237538 & 0.215416 & 1.000000 & \\
\hline CPS & 0.085733 & -0.154942 & 0.170363 & 0.048370 & 1.000000 \\
\hline
\end{tabular}

Source: Researchers' Computation, 2019.

Table 2. ADF Unit Root Result

\begin{tabular}{|c|c|c|c|c|c|c|c|}
\hline \multicolumn{4}{|c|}{ Level Form } & \multicolumn{4}{|c|}{ First Differences } \\
\hline Variables & T-stat & $\begin{array}{c}5 \% \text { Critical } \\
\text { Value }\end{array}$ & P-value & T-stat & $\begin{array}{c}5 \% \text { Critical } \\
\text { Value }\end{array}$ & P-value & $\begin{array}{l}\text { Order } \\
\text { of Int. }\end{array}$ \\
\hline INO & $/ 1.478030 /$ & $/ 3.595026 /$ & 1.0000 & /6.440221/ & /3.595026/ & 0.0001 & $1(1)$ \\
\hline
\end{tabular}


ISSN (online) - 2521-1242 ISSN (print) - 2521-1250

\begin{tabular}{|c|c|c|c|c|c|c|c|}
\hline TOP & $/ 2.735081 /$ & $/ 3.562882 /$ & 0.2305 & $/ 7.110018 /$ & $/ 3.568379 /$ & 0.0000 & $1(1)$ \\
\hline EXR & $/ 1.784322 /$ & $/ 2.960411 /$ & 0.9995 & $/ 3.140530 /$ & $/ 2.963972 /$ & 0.0341 & $1(1)$ \\
\hline GCS & $/ 0.539267 /$ & $/ 2.963972 /$ & 0.8696 & /7.091857/ & $/ 2.963972 /$ & 0.0000 & $1(1)$ \\
\hline CPS & 0.333494 & 3.562882 & 0.9858 & $/ 6.475275 /$ & $/ 3.568379 /$ & 0.0000 & $1(1)$ \\
\hline
\end{tabular}

Source: Researchers' Computation, 2019.

Table 3. Johansen Co-integration Test (Trace and Max-Eigen Statistic)

\begin{tabular}{|c|c|c|c|c|c|c|}
\hline $\begin{array}{l}\text { Hypothesized } \\
\text { No. of CE(s) }\end{array}$ & $\begin{array}{l}\text { Trace } \\
\text { Statistic }\end{array}$ & $\begin{array}{l}\text { P.05 } \\
\text { Critical Value }\end{array}$ & Prob. ${ }^{* *}$ & $\begin{array}{l}\text { Max-Eigen } \\
\text { Statistic }\end{array}$ & $\begin{array}{l}0.05 \\
\text { Critical Value }\end{array}$ & Prob.** \\
\hline None & 107.3220 & 76.97277 & $0.0000^{* *}$ & 51.76491 & 34.80587 & $0.0002^{* *}$ \\
\hline At most 1 & 55.55709 & 54.07904 & $0.0367 * *$ & 26.20002 & 28.58808 & 0.0979 \\
\hline At most 2 & 29.35707 & 35.19275 & 0.1858 & 16.59933 & 22.29962 & 0.2578 \\
\hline At most 3 & 12.75774 & 20.26184 & 0.3835 & 8.326818 & 15.89210 & 0.5092 \\
\hline At most 4 & 4.430927 & 9.164546 & 0.3517 & 4.430927 & 9.164546 & 0.3517 \\
\hline
\end{tabular}

Source: Researchers' Computation, 2019.

Table 4. Error Correction Model. Dependent Variable: D(LOG(INO))

\begin{tabular}{|c|r|r|r|r|}
\hline Variables & Coefficient & Std. Error & t-Statistic & Prob. \\
\hline ECM(-1) & -0.783707 & 0.211354 & -3.708038 & 0.0012 \\
\hline D(LOG(INO(-1)) & 0.567399 & 0.237695 & 2.387088 & 0.0256 \\
\hline D(LOG(TOP)) & -0.123189 & 0.092045 & -1.338367 & 0.1939 \\
\hline D(LOG(EXR)) & 0.122038 & 0.069660 & 1.751919 & 0.0931 \\
\hline D(LOG(GCS)) & 0.116934 & 0.038851 & 3.009806 & 0.0062 \\
\hline D(LOG(CPS)) & -0.471573 & 0.200258 & -2.354827 & 0.0274 \\
\hline C & 0.166670 & 0.050689 & 3.288108 & 0.0032 \\
\hline
\end{tabular}

\begin{tabular}{|l|c|}
\hline \multicolumn{1}{|c|}{$\mathrm{C}$} & 0.166670 \\
\hline R-squared & 0.712054 \\
\hline F-statistic & 0.684764 \\
\hline Prob(F-statistic) & 4.022727 \\
\hline Durbin-Watson stat & 0.006711 \\
\hline
\end{tabular}

Source: Researchers' Computation, 2019.

Table 5. Diagnostics

\begin{tabular}{|l|l|l|}
\hline Diagnostics test & \multicolumn{1}{|c|}{ Observed value } & \multicolumn{1}{c|}{ P-value (Chi-square) } \\
\hline Normality Test & 2.264432 & 0.35256 \\
\hline Breusch-Godfrey LM test for autocorrelation & 4.420968 & 0.1096 \\
\hline Heteroskedasticity Test: Breusch-Pagan-Godfrey & 13.17299 & 0.2142 \\
\hline
\end{tabular}

Source: Researchers' Computation, 2019.

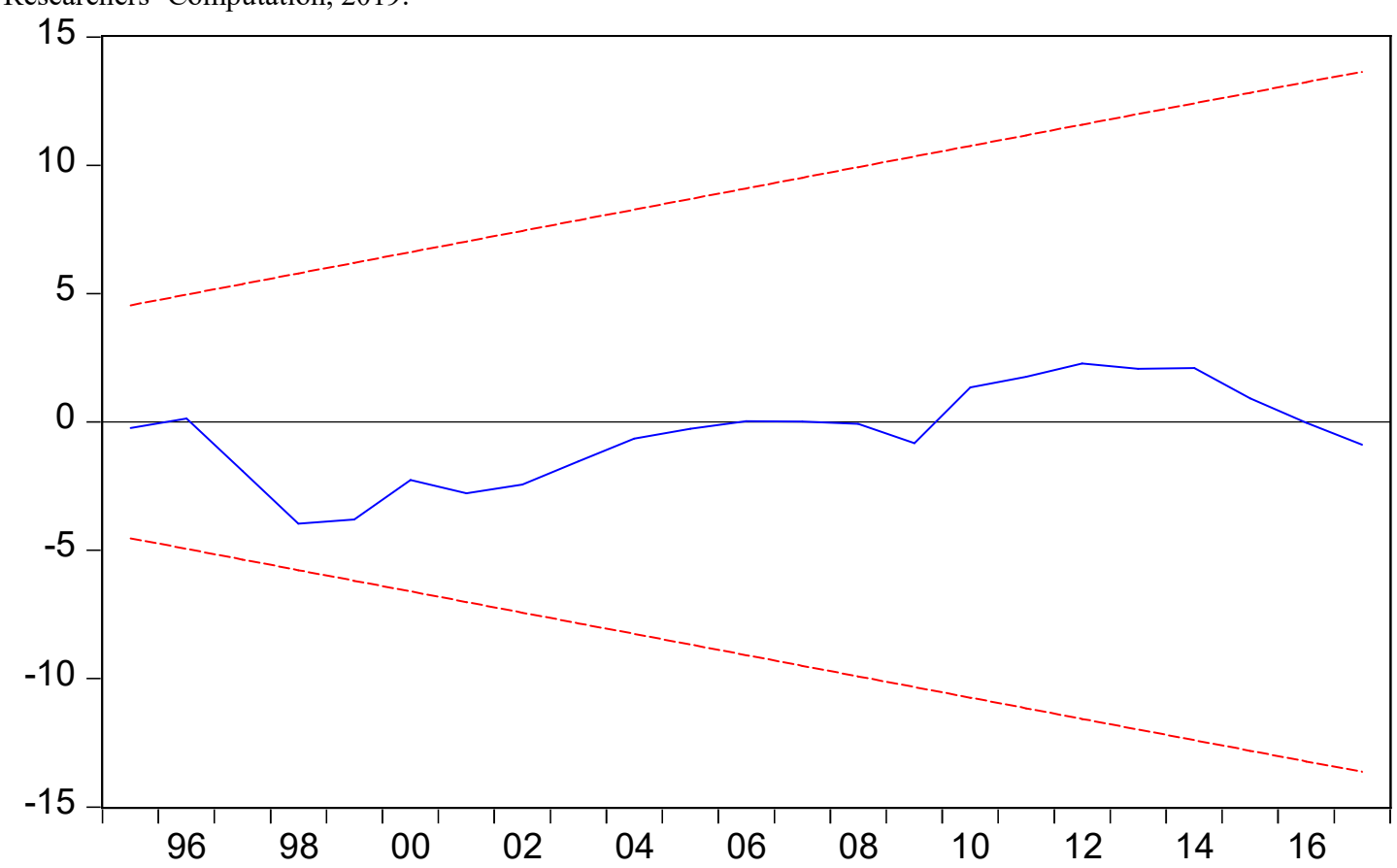

\footnotetext{
CUSUM ---- 5\% Significance

Figure 1 Cusum Stability Test
}

Source: Authors' Computation 2019/E-views 
ISSN (online) - 2521-1242 ISSN (print) - 2521-1250

Table 6. Pairwise Granger Causality Tests

\begin{tabular}{|l|c|c|c|c|}
\hline \multicolumn{1}{|c|}{ Null Hypothesis: } & Obs & F-Statistic & Prob. & Result \\
\hline TOP does not Granger Cause INO & 30 & 0.72906 & 0.4923 & Independent \\
INO does not Granger Cause TOP & & 2.39368 & 0.1119 & Causality \\
\hline INO does not Granger Cause EXR & 30 & 8.27795 & 0.0017 & Bidirectional \\
EXR does not Granger Cause INO & & 3.50425 & 0.0455 & Causality \\
\hline GCS does not Granger Cause INO & 30 & 1.70841 & 0.2016 & Independent \\
INO does not Granger Cause GCS & & 0.28771 & 0.7524 & Causality \\
\hline INO does not Granger Cause CPS & & 7.48909 & 0.0028 & Bidirectional \\
CPS does not Granger Cause INO & 30 & 3.74567 & 0.0378 & Causality \\
\hline
\end{tabular}

Source: Researchers' Computation, 2019. 